\title{
Moderni yritysten välinen suhdemyynti korostaa vuorovaikutusosaamisen merkitystä
}

\author{
Jonna Koponen
}

\begin{abstract}
Viittausohje:
Koponen, J. (2022). Moderni yritysten välinen suhdemyynti korostaa vuorovaikutusosaamisen merkitystä. Prologi - Viestinnän ja vuorovaikutuksen tieteellinen aikakauslehti, 17(1), 56-61.

https://doi.org/10.33352/prlg.113559

To cite this article:

Koponen, J. (2022). Moderni yritysten välinen suhdemyynti korostaa vuorovaikutusosaamisen merkitystä [Modern B2B relationship selling emphasizes the importance of sales communication competence]. Prologi

- Journal of Communication and Social Interaction, 17(1), 56-61. https://doi.org/10.33352/prlg.113559
\end{abstract}

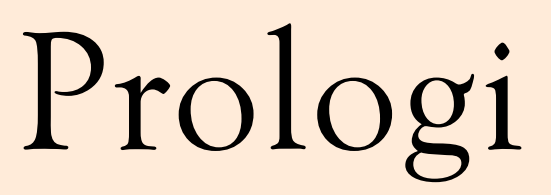

\section{- Viestinnän ja vuorovaikutuksen tieteellinen aikakauslehti journal.fi/prologi/}

ruotsiksi: Prologi - Tidskrift för Kommunikation och Social Interaktion englanniksi: Prologi - Journal of Communication and Social Interaction

Julkaisija: Prologos ry.

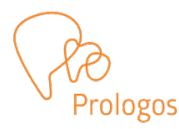

Avoin julkaisu / Open Access

ISSN 2342-3684 / verkko

ISSN 1795-7613 / painettu versio 


\title{
Lectio Praecursoria
}

Prologi, 17(1)

$56-61$

https://doi.org/10.33352/prlg.113559

(c) (i)

CC BY-NC-SA 4.0

\section{Moderni yritysten välinen suhdemyynti korostaa vuorovaikutusosaamisen merkitystä}

\author{
Jonna Koponen \\ FT, akatemiatutkija \\ Itä-Suomen yliopisto \\ jonnapauliina.koponen@uef.fi
}

vastaanotettu 7.12.2021 / hyväksytty 8.12.2021 / julkaistu 21.1.2022

ASIASANAT: Yritysten välinen suhdemyynti, myynnin vuorovaikutusosaaminen, sosiaalinen läsnäolo, sosiaalisen läpäisyn teoria

FT Jonna Koposen palvelujohtamisen alaan kuuluva väitöskirja Sales communication competence in modern B2B relationship selling (suom. Myynnin vuorovaikutusosaaminen modernissa yritysten välisessä suhdemyynnissä) tarkastettiin yhteiskuntatieteiden ja kauppatieteiden tiedekunnassa Kuopion kampuksella, Mediastudia-rakennuksen MS300-salissa 3.12.2021 klo 12. Vastaväittäjänä toimi professori Pauliina Ulkuniemi Oulun yliopistosta ja kustoksena professori Anu Puusa Itä-Suomen yliopistosta.

Väitöskirja on luettavissa verkossa osoitteessa http://urn.fi/URN:ISBN:978-952-61-4383-5 
Jos ajattelette sanaa myynti, mitä teille tulee mieleen? Mietittekö koulun varainkeruukampanjaa, jonka tavoitteena on myydä paikallista kahvia ja kerätä rahaa luokkaretkeä varten? Vai tuliko mieleenne ärsyttävä puhelinmyyjä, joka tyrkyttää lehtitilausta, jota ette tarvitse? Myyntiin liittyy monenlaisia mielikuvia, mutta tyrkyttämisen vastakohtana on asiakaslähtöinen ajattelu, jolloin myynti nähdään asiakkaan palveluna ja ratkaisujen tarjoamisena hänen tarpeisiinsa. Asiakassuhteisiin pohjautuvaa markkinointia ja johtamista pidetäänkin vaihtoehtona kertaluontoiselle myynnille tai palvelujen ja tuotteiden vastikkeelliselle vaihdolle. Kun yritys on valinnut palvelunäkökulman strategiseksi lähestymistavaksi, on välttämätöntä ymmärtää myös asiakassuhteisiin perustuvaa myyntiä.

Myynti on ilmiönä ikivanha ja myynnin akateemisten juurten nähdään ulottuvan jo Antiikin Kreikkaan, sillä kreikkalaisen filosofin Platon tiedetään kirjoittaneen myyjistä (salesmen). Ensimmäiset myyjät, jotka ansaitsivat elantonsa pelkästään tekemällä myyntityötä, ilmestyivät teollisen vallankumouksen aikaan Englannissa 1700-luvun lopulla. Tänä vuonna myynnin tutkijat Adam Rapp ja Lisa Beeler (2021) julkaisivat kirjallisuuskatsauksen myynnin ja myynnin johtamisen tutkimuksesta. Heidän mukaansa ensimmäinen myyntiä käsitellyt tieteellinen tutkimus voidaan jäljittää Journal of Applied Psychology -lehdessä vuonna 1918 julkaistuun artikkeliin, jossa tutkija Elsie Oschrin keskittyi tarkastelemaan vähittäiskaupassa työskentelevien naisten myyntitaitoja. Eli yli sata vuotta sitten. Myyntiä on sen jälkeen tutkittu monista näkökulmista. Keskeisiä tutkimuskohteita ovat olleet esimerkiksi myyntiprosessi, myyjien rekrytointi ja motivoiminen, sekä myyjän ja asiakkaan välinen vuorovaikutus.
Väitöstutkimuksessani määrittelen myynnin niin, että se on organisaatioiden ja ihmisten välistä vuorovaikutusta, jonka tavoitteena on tuottaa asiakkaalle arvoa sekä edistää liiketaloudellista vaihtoa (Dixon \& Tanner, 2012). Tutkimukseni teoriatausta keskittyy yritysten väliseen suhdemyyntiin (Arli, Bauer \& Palmatier, 2018). Se on tällä hetkellä yleisimmin käytetty yritysten välisen myynnin teoreettinen lähtökohta sekä tutkimuksessa että käytännön liikeelämässä.

Suhdemyynnin tavoitteena on luoda luottamusta asiakkaan ja myyjän välille rakentaen pitkäaikaisia, tuottavia asiakassuhteita (Habel, Alavi \& Linsenmayer, 2021). Vuorovaikutuksessa rakentuva luottamus on perusta asiakassuhteen syntymiselle ja eettisesti kestävälle myyntityölle. Myyjän asiakasorientaatio, mukautuva myyntityyli ja suhteeseen panostaminen tutkitusti edistävät asiakassuhteiden jatkumista. Samaan aikaan pyritään välttämään sellaisia toimintoja, jotka voivat vaarantaa suhteen olemassaolon, kuten myyntiorientaatiota tai manipulatiivisten myyntitaktiikoiden käyttöä. Asiakassuhteiden luomiseen ja ylläpitämiseen puolestaan tarvitaan myynnin vuorovaikutusosaamista, jota palvelujohtamisen alaan kuuluvassa väitöskirjassani olen tutkinut.

Miksi tutkimukseni aihe on niin ajankohtainen? Siksi, että suhdemyynnin kenttä on muuttunut voimakkaasti, ja käytänkin työssäni termiä moderni yritysten välinen suhdemyynti. Muutos liittyy seuraaviin asioihin: ensinnäkin viime vuosina teknologinen kehitys on ollut nopeaa ja digitalisaatio on vauhdittanut myynnin muutosta. Kilpailusta on tullut globaalia ja asiakkaat tarvitsevat yhä monimutkaisempia ratkaisuja. Myös verkkokaupan suosio on kasvanut viime aikoina runsaasti. Myynnissä hyödynnetään sosiaalisen median kanavia, erilaisia tietokantoja, tekoälyä ja digitaalisia alustoja. 
Toiseksi globaali koronaviruspandemia muutti myyntivuorovaikutuksen suurelta osin digitaaliseksi. Kaupallisten selvitysten mukaan sekä yritysasiakkaat että myyjät haluavat olla vuorovaikutuksessa mieluummin digitaalisesti kuin fyysisesti kasvokkain. Suomalaiset pörssiyhtiöt, kuten Wärtsilä, Metso-Outotec ja Valmet, ovat säästäneet miljoonia euroja, kun työmatkat ovat korvautuneet videoyhteyksin hoidettavilla asiakaskohtaamisilla. Digitaalinen asiakaskohtaaminen on kustannustehokas, nopeasti toteutettava, ekologinen ja terveysturvallinen vaihtoehto.

Kolmanneksi asiakkaat etsivät aktiivisesti tietoa yrityksestä, tuotteista ja palveluista, sen sijaan että he ottaisivat suoraan yhteyttä myyjään tai yritykseen. Niinpä myyjät kohtaavat yhä valistuneempia asiakkaita, jotka tietävät mitä tahtovat. Neljänneksi asiakasvuorovaikutuksesta on tullut monikanavaista. Yritysten välisessä myynnissä asiakassuhteet voidaan luoda ja ylläpitää puhelimen, sosiaalisen median sovellutusten, tekstiviestien, sähköpostin ja videotapaamisten avulla - kasvokkainen fyysinen kohtaaminen tapahtuu myöhemmin myyntiprosessin aikana, jos on edes tarpeen tavata.

Edellä kuvattu muutos asettaa uusia osaamisvaatimuksia myyjille sekä myynti- ja markkinointijohtajille. Suhdemyynnin tutkimuskentällä on tarkasteltu kuitenkin vielä vähän myyjien vuorovaikutusosaamisen tarpeiden muutoksia. Aiemmin on tutkittu myyjien vuorovaikutustaitoja, myyntiin liittyviä tietoja ja vaikkapa myyntipuheluiden soittamiseen liittyvää jännittämistä (Habel ym., 2021; Rapp \& Beeler, 2021). Tutkimuksissa on esimerkiksi havaittu, että onnistuneeksi koettu vuorovaikutus on yhteydessä luottamuksen rakentumiseen, sitoutumiseen, asiakastyytyväisyyteen sekä asiakkaan kokemaan suhteen laatuun (Habel ym., 2021). Myyjän tärkeitä vuorovaikutus- taitoja ovat esimerkiksi kuuntelemisen taito, taito esittää kysymyksiä asiakkaan tarpeiden kartoittamiseksi ja taito nähdä vaivaa asiakkaan palvelemiseksi. Kirjallisuus on kuitenkin pirstaleista ja monikäsitteistä. Sen takia olen tuonut väitöskirjaani vuorovaikutusosaamisen käsitteen, jonka näin kokoavana teoreettisena ymmärryksenä ja jota lähdin soveltamaan tutkimuksessani.

\section{Myynnin vuorovaikutusosaamisen tutkimisen tarve}

Työni keskiössä olevan vuorovaikutusosaamisen käsitteen teoriapohjan ovat luoneet 1980-luvulla tutkijat Brian Spitzberg ja William Cupach. Vuorovaikutusosaaminen tarkoittaa ihmisten väliseen vuorovaikutukseen liittyviä tietoja, taitoja, asennoitumista ja ymmärrystä, joita asiantuntija tarvitsee työssä menestyäkseen. Se on viestintätilanteeseen, -suhteeseen ja ympäröivään kulttuuriin nähden tehokasta, tarkoituksenmukaista ja eettistä toimintaa. Lähestyn vuorovaikutusosaamista verbaalisena ja nonverbaalisena viestintänä, jota tarvitaan modernin yritysten välisen suhdemyynnin kontekstissa. Näen vuorovaikutusosaamisen erottamattomana osana myynnin asiantuntijan työtä. Sitä tarvitaan, kun viestitään asiakkaiden, toisten myynnin asiantuntijoiden, sekä muiden tärkeiden toimijoiden kanssa. Vuorovaikutusosaamista on aiemmin tarkasteltu useisiin eri ammattialoihin liittyen, on tarkasteltu esimerkiksi lääkärin, poliitikon, opettajan tai farmaseutin vuorovaikutusosaamista. Tämä työ on kuitenkin ensimmäinen, jossa tarkastellaan myynnin vuorovaikutusosaamista.

Tutkimukseni tarve perustuu aiemman kirjallisuuden analysoinnin pohjalta muodostettuun tutkimusaukkoon. Ensinnäkin, vaikka interpersonaalisen eli kahden ihmisen tai pie- 
nen ryhmän välisen vuorovaikutuksen merkitys myynnin onnistumisessa on tunnistettu jo kauan sitten, myyntiympäristön muutokset asettavat uusia osaamisvaatimuksia myynnin asiantuntijoille. Nykyinen tutkimus ei tuota riittävää teoreettista ymmärrystä myynnin vuorovaikutusosaamisesta.

Toiseksi, koska myyntivuorovaikutus tapahtuu yhä enemmän digitaalisissa viestintäkanavissa, on tarpeen ymmärtää sosiaalista läsnäoloa näissä kanavissa. Tutkimuksessani sosiaalinen läsnäolo tarkoittaa tunnetta kontaktista aidon ihmisen kanssa. Yritykset ovat yhä kiinnostuneempia siitä, kuinka verkkokauppaan voidaan lisätä sosiaalisen läsnäolon elementtejä, sillä se edistää asiakkaan luottamusta palveluntarjoajaa kohtaan. Yksi tapa lisätä vuorovaikutteisuutta on chat-palvelun käyttö verkkosivustolla. Vielä ei kuitenkaan tiedetä, miten sosiaalinen läsnäolo näyttäytyy yritysasiakkaiden ja myyjien chat-keskusteluissa.

Kolmanneksi, vaikka asiakassuhteiden kehittymistä on tutkittu jo useiden vuosikymmenten ajan, meillä on edelleen vähän tietoa siitä, millaisten interpersonaalisen tason mekanismien kautta asiakassuhteet rakentuvat henkilökohtaisella tasolla. Henkilökohtaisuus on tärkeää, koska vahvat sosiaaliset siteet liikekumppaneiden välillä pitävät heitä yhdessä vaikeinakin aikoina. Vielä emme kuitenkaan tiedä, miten itsestäkertomisen mekanismi tai relationaalisten hyötyjen ja haittojen arviointi näkyvät asiakassuhteiden rakentumisessa.

\section{Tutkimuksen tavoitteet}

Väitöskirjatutkimukseni koostuu kolmesta artikkelista ja niiden yhteenvedosta. Ensimmäisen artikkelin tavoitteena oli tuottaa syvällinen ymmärrys siitä, kuinka myynnin vuorovaiku- tusosaaminen voidaan määritellä. Otin huomioon erityisesti kansainvälisen toimintaympäristön sekä ratkaisun rakentamisen tarpeet. Toisessa artikkelissa pureuduin digitaaliseen vuorovaikutukseen. Tavoitteena oli ymmärtää sosiaalisen läsnäolon merkitystä chat-keskusteluissa. Kolmannen artikkelin tavoitteena oli ymmärtää ja kuvata asiakassuhteiden kehittymistä sosiaalisen läpäisyn teorian näkökulmasta keskittyen erityisesti itsestäkertomiseen ja asiakassuhteeseen liittyvään relationaaliseen hyöty- ja haitta-arvioon. Väitöskirjan yhteenvedon tavoitteena on koota tulokset yhteen ja tuottaa uusi kokonaisvaltainen ymmärrys tutkittavasta ilmiöstä.

Artikkelissa numero yksi (Koponen, Julkunen \& Asai, 2019) teoriatausta sisälsi vuorovaikutusosaamisen teorian sekä laajan kirjallisuuskatsauksen myynnin vuorovaikutusta käsittelevään kirjallisuuteen. Tutkimuskysymys oli: Kuinka vuorovaikutusosaaminen voidaan käsitteellistää kansainvälisen yritysten välisen suhdemyynnin kontekstissa, jossa myyjät rakentavat monimutkaisia ratkaisuja asiakkailleen? Aineisto koostui 39 puolistrukturoidusta kansainvälisten myyjien, myyntijohtajien ja kansainvälisten myynnin opettajien asiantuntijahaastatteluista. Analyysimenetelmänä käytin teoriasidonnaista teema-analyysiä. Keskeisin tulos oli myynnin vuorovaikutusosaamisen käsite, jossa on neljä dimensiota.

Artikkelissa numero kaksi (Koponen \& Rytsy, 2020) teoriataustaan kuului sosiaalinen läsnäolo sekä digitaalisen myyntivuorovaikutuksen kirjallisuuskatsaus. Tutkimuskysymykset olivat: Kuinka sosiaalinen läsnäolo näyttäytyy myyjien ja asiakassuhteen eri vaiheessa olevien asiakkaiden välisissä chat-keskusteluissa? Kuinka chat-palvelun käyttötarkoitukset vaihtelevat, kun asiakkaat ovat asiakassuhteen eri vaiheissa? Aineisto koostui 157 chat-keskustelusta sekä 
yrityksen CRM-datasta, jonka perusteella oli mahdollista jäljittää chat-palvelua käyttäneiden asiakkaiden asiakassuhteen vaihe. Analyysimenetelmänä käytin teoriasidonnaista teema-analyysiä. Keskeisin tulos oli asiakassuhdetta ylläpitävän sosiaalisen läsnäolon tunnistaminen. Sen lisäksi sosiaalinen läsnäolo näkyi interaktiivisina ja affektiivisina viesteinä. Keskeisimmät käyttötarkoitukset olivat tiedonhaku, ongelmanratkaisu ja ratkaisumyyjän tavoittaminen.

\section{Kolmannessa artikkelissa (Koponen \&} Julkunen, prosessissa) teoriatausta koostui sosiaalisen läpäisyn teoriasta ja laajasta kirjallisuuskatsauksesta aiempaan asiakassuhteiden kehittymistä sekä itsestäkertomista käsitelleeseen tutkimukseen. Tutkimuskysymykset olivat: Kuinka ja miksi myyjän arvio pitkäaikaisen ja tuottavan asiakassuhteen relationaalisista hyödyistä ja haitoista syventää tai ei syvennä asiakassuhdetta? Kuinka ja miksi myyjän itsestäkertominen ja liiketoimintaan liittyvä kertominen syventää tai ei syvennä asiakassuhdetta? Aineisto koostui 47 puolistrukturoidusta asiantuntijahaastattelusta. Analyysimenetelmänä käytin merkitysten muutokseen keskittyvää teema-analyysiä. Keskeisin tulos oli uusi teoreettinen malli yritysten välisten asiakassuhteiden kehittymisestä sekä kontekstuaalinen laajennus sosiaalisen läpäisyn teoriaan. Asiakassuhteiden kehittymiseen löytyi kolme vaihetta. Syvimmällä tasolla osapuolet kertoivat toisilleen hyvin henkilökohtaisia ja sensitiivisiä asioita. Itsestäkertominen osoittautui tärkeäksi asiakassuhteita syventäväksi mekanismiksi.

Väitöskirjatutkimuksen keskeinen teoreettinen johtopäätös perustuu osa-artikkeleiden tulosten yhteenvetoon. Osatutkimukset tuottivat kukin uutta ymmärrystä myynnin vuorovaikutusosaamisesta. Ensimmäinen artikkeli tuotti pohjan uudelle käsitteelle. Toinen ja kolmas artikkeli tuottivat kumpikin uutta ymmärrystä asiakassuhteen vaiheen merkityksestä sekä digitaalisesta että monikanavaisesta myyntivuorovaikutuksesta.

\section{Tutkimuksen teoreettinen ja käytännöllinen kontribuutio}

Johtopäätöksenä esitän, että myynnin vuorovaikutusosaaminen sisältää neljä keskeistä dimensiota: myynnin strategisen osaamisen, vuorovaikutustaidot, viestinnän kognitiivisen ulottuvuuden sekä viestinnän affektiivisen ulottuvuuden. Myynnin strategiseen osaamiseen kuuluu strateginen ymmärrys yritysten välisestä myynnistä, myyntiprosessista ja asiakkaan ostokäyttäytymisestä; strateginen ymmärrys erilaisista myyntiviestintäkanavista ja niiden käytöstä; sekä johtamisosaaminen.

Vuorovaikutustaidot liittyvät taitoihin luoda ja ylläpitää asiakassuhteita, henkilökohtaisiin myyntitaitoihin sekä kielitaitoon. Viestinnän affektiivinen ulottuvuus tarkoittaa motivaatiota olla vuorovaikutuksessa erilaisten asiakkaiden kanssa, myönteistä ja avointa asennetta sekä kulttuurista sensitiivisyyttä. Viestinnän kognitiiviseen ulottuvuuteen kuuluu ymmärrys viestinnän ilmiöistä, kuten sanattomasta viestinnästä ja neuvottelutyyleistä. Siihen liittyy myös ymmärrys asiakassuhteen vaiheista ja niiden vaikutuksesta myyntivuorovaikutukseen, tieto erilaisista kansallisista kulttuureista sekä oman viestinnän reflektointitaito.

Myynnin vuorovaikutusosaamisen tärkeimmät kriteerit ovat tehokkuus, tarkoituksenmukaisuus ja eettisyys. Tehokkuus tarkoittaa, että myyntivuorovaikutuksessa osapuolten on mahdollista saavuttaa tavoitteensa. Tarkoituksenmukaisuus liittyy siihen, että myyntivuorovaikutus on sopivaa suhteessa sosiaalisiin normeihin, osapuolten väliseen vuorovaikutus- 
suhteeseen, viestintäkanaviin, viestintätilanteeseen sekä kulttuuriseen ympäristöön. Eettisyys viittaa haluun ja taitoon toimia moraalisesti vastuuntuntoisesti sekä niin, että viestintä ei ole epäluotettavaa, loukkaavaa tai toisia vahingoittavaa.

Kaiken kaikkiaan väitöskirjatutkimukseni tulokset auttavat kehittämään myynti- ja johtamiskoulutusta. Myynnin vuorovaikutusosaaminen tulisi huomioida esimerkiksi myyjien rekrytoinnissa ja koulutuksessa, sekä heidän roolituksessaan myyntitiimissä. Tulosten avulla voidaan kehittää yritysten digitaalisia palveluja asiakasvuorovaikutuksen näkökulmasta, ja parantaa esimerkiksi chat-palvelun laatua. Lisäksi tulokset kannustavat yritysjohtajia huomioimaan interpersonaalisen tason myös yrityksen strategisessa ajattelussa ja personoidussa asiakassuhteen hoidossa. Pitkäaikaisten, tuottavien asiakassuhteiden ylläpitäminen on ensiarvoista etenkin niille yrityksille, joissa palvelunäkökulma on valittu strategiseksi lähestymistavaksi.

\section{Kirjallisuus}

Arli, D., Bauer, C., \& Palmatier, R. W. (2018). Relational selling: Past, present and future. Industrial Marketing Management, 69, 169-184.

Dixon, A.L. \& Tanner, J. F (Jr.) (2012). Transforming selling: Why it is time to think differently about sales research. Journal of Personal Selling \& Sales Management, 32(1), 9-13.

Habel, J., Alavi, S. \& Linsenmayer, K. (2021). From personal to online selling: How relational selling shapes salespeople's promotion of e-commerce channels. Journal of Business Research, 132, 373-382.
Oshrin, E. A. (1918). Vocational tests for retail saleswomen. Journal of Applied Psychology, 2(2), 148-155.

Koponen, J., Julkunen, S. \& Asai, A. (2019). Sales communication competence in international B2B solution selling. Industrial Marketing Management, $82,238-252$.

Koponen, J. \& Rytsy, S. (2020). Social presence and e-commerce B2B chat functions. European Journal of Marketing, 54(6), 1205-1224.

Koponen, J. \& Julkunen, S. Interpersonal-level exploration on B2B customer relationship development. (prosessissa) European Journal of Marketing.

Rapp, A. \& Beeler, L. (2021). The state of selling and sales management research: a review and future research agenda. Journal of Marketing Theory and Practice, 29(1), 37-50.

\section{TITLE AND KEYWORDS IN ENGLISH:}

Modern B2B relationship selling emphasizes the importance of sales communication competence KEYWORDS: B2B relationship selling, sales communication competence, social presence, social penetration theory 